\title{
Regulatory Submission Receipt Date and Time
}

National Cancer Institute

\section{Source}

National Cancer Institute. Regulatory Submission Receipt Date and Time. NCI Thesaurus. Code C70864.

Physical media documenting the date and time when a regulatory submission is received in the FDA Document Room. This is an official receipt for the regulatory submission time. A submission receipt date might be different from a submission date. Submissions received outside of official hours are dated the next business day. 